\title{
Moraxella lincolnii
}

National Cancer Institute

\section{Source}

National Cancer Institute. Moraxella lincolnii. NCI Thesaurus. Code C86527.

A species of aerobic, Gram negative, coccobacilli shaped bacteria assigned to the phylum Proteobacteria. This species is oxidase and catalase positive, urease and alkaline phosphatase negative, nonmotile, relatively halointolerant, susceptible to penicillin, grows on blood agar or nutrient agar and does not reduce nitrate. M. lincolnii has been isolated from humans with respiratory infections. 